\title{
Study of Covid-19 Prevention: Diet and Physical Activity During Large-Scale Social Restrictions in West Sumatera
}

\author{
Yeffi Masnarivan ${ }^{1 *}$ Arinil Haq $^{1}$ Anggela Pradiva Putri ${ }^{1}$ \\ ${ }^{1}$ Faculty of Public Health, Universitas Andalas, Padang, Sumatera Barat 25163, Indonesia \\ "Corresponding author.Email: veffimasnarivan@ph.unand.ac.id
}

\begin{abstract}
Coronavirus Disease or known as COVID-19 is currently a global health problem. COVID-19 is a new disease caused by a virus called Sars-Cov-2. The first case in West Sumatera Province was reported on March 18, 2020. As of May 2, 2020, total of 182 positive cases of COVID-19 have been confirmed in West Sumatera Province. The Government of the Republic of Indonesia has issued Government Regulation Number 21 of 2020 concerning Large-Scale Social Restrictions (PSBB) in the framework of the Acceleration of Handling COVID19. Therefore this study aims to determine dietary pattern and physical activity of the people in West Sumatera during the PSBB during the COVID-19 pandemic in 2020. This research is a quantitative study using survey approach. The results showed that more than half of the respondents sometimes eat snacks every day. Nearly half of the respondents consumed fresh food every day, sometimes consumed processed food the last few days, ate side dishes containing animal protein, and sometimes ate more portions during PSBB. The physical activities that are often carried out by respondents during the PSBB are washing / cooking / sweeping / mopping, walking, aerobics, playing video games, gardening and other physical activity. It is recommended that people maintain a balanced diet and regularly carry out physical activities, especially during this pandemic.
\end{abstract}

Keywords: COVID-19, diet, physical activity, PSBB

\section{INTRODUCTION}

Coronavirus Disease or known as COVID-19 is currently a global health problem. COVID-19 is a new disease caused by a virus called Sars-Cov-2. COVID-19 began to be reported in Indonesia with 2 positive confirmation cases on March 2, 2020 [1]. As of May 2, 2020, total of 10,551 positive cases have been confirmed in Indonesia with a CFR of $7.58 \%$ [2]. Meanwhile, in West Sumatera Province, the first case was reported on March 18, 2020. Total of 182 positive cases of COVID-19 have been confirmed in West Sumatera Province as of May 2, 2020 [3]. COVID-19 is spread mainly through close contact from person to person in the droplet of an infected person. Infected people often have symptoms of the disease, some are asymptomatic but can still spread the virus. In addition, viruses can spread through contact with contaminated goods or surfaces [4].

The Government of the Republic of Indonesia has issued Government Regulation Number 21 of 2020 concerning Large-Scale Social Restrictions (PSBB) in the framework of the Acceleration of Handling COVID-19. PSBB is based on epidemiological considerations, the magnitude of threats, effectiveness, resource support, operational technical, political, economic, social, cultural, defense and security considerations. PSBB at least includes school and workplace, entertainment, restrictions on religious activities, and / or restrictions on activities in public places or facilities [5].

PSBB is proposed by the Governor / Regent / Mayor to the Minister of Health. The Governor/Regent / Mayor in submitting a proposal for PSBB to the Minister must comply with the following data: increase in the number of cases according to time; distribution of cases over time; and local transmission events [6]. The Province of West Sumatera has been designated to carry out the PSBB through the Decree of the Minister of Health of the Republic of Indonesia Number HK.01.07 / MENKES / 260/2020 concerning the Determination of the PSBB in the West Sumatera Province Region in the Framework of Accelerating the Handling of COVID-19. The implementation of PSBB in West Sumatera Province for 14 days starting from April 22 to May 5, 2020 for phase 1 [7]. The PSBB was extended to phase 2 until 29 May 2020, then extended more to phase 3 until 7 June 2020. The onset of the COVID-19 pandemic, the status of the emergency response followed by the PSBB policy will have a significant impact not only on community activities but also on the economic conditions of the majority of people 
working in the informal sector. It is feared that this condition will affect the decline in access and purchasing power of the people towards fulfilling nutritious food [8]. West Sumatera Province has experienced negative economic growth in the second quarter of 2020 due to the impact of the COVID-19 pandemic. The implementation of the PSBB policy has contributed to the economy of West Sumatera Province [9].

A healthy diet and balanced nutrition is very important especially during the COVID-19 pandemic. The food and drinks we consume can have some effects on the body's ability to prevent, fight and recover from infection [10]. People who eat balanced diet tend to be healthier with a stronger immune system and a lower risk of chronic diseases and infectious diseases [11].

In addition to dietary pattern, regular physical activity is beneficial for the body and mind [12]. Physical activity according to WHO is any bodily movement produced by skeletal muscles that requires energy expenditure, including carrying out household chores, playing, activities undertaken while working, and engaging in recreational pursuits [13]. Physical activity can reduce high blood pressure, help manage weight and reduce the risk of heart disease, stroke, type 2 diabetes, and various cancers. Where all these conditions can increase susceptibility to COVID-

19 [12]. Therefore this study aims to describe dietary pattern and physical activity of the people in West Sumatera during the PSBB during the COVID-19 pandemic in 2020.

\section{METHOD}

This research is a quantitative study using survey approach. The variables in this study were the characteristics of respondents (gender, age, marital status, occupation, residential status), community eating patterns during PSBB and physical activities in the community in West Sumatera Province during PSBB.

The study was conducted from April 30 to May 52020 with questionnaires using the Google form platform and then distributed through various internet platforms such as WhatsApp and Facebook. The population in this study are all people who live in West Sumatera Province. While the research sample is part of the population, namely the people of West Sumatera Province who fill out the questionnaire. Total of 427 respondents were included. Univariate analysis is used to describe the frequency distribution of each variable under study, namely respondents characteristics, diet, and physical activity.

\section{RESULT}

\subsection{Respondent Characteristics}

Respondent characteristics in this study describe the variables of sex, age group and working conditions. Most respondents were male $(67.4 \%)$. Most respondents in the age group of 21-30 years old (41.9\%). And among those respondents who work, $40 \%$ of them were working from home (Table 1).

Table 1 Respondent Characteristics

\begin{tabular}{|l|c|c|}
\hline \multicolumn{1}{|c|}{ Variable } & f & \% \\
\hline Sex & & \\
\hline Male & 139 & 32.6 \\
\hline Female & 288 & 67.4 \\
\hline Total & $\mathbf{4 2 7}$ & $\mathbf{1 0 0 . 0}$ \\
\hline Age group & & \\
\hline $15-20$ & 63 & 14.8 \\
\hline $21-30$ & 179 & 41.9 \\
\hline $31-40$ & 104 & 24.4 \\
\hline $41-50$ & 52 & 12.2 \\
\hline $51-60$ & 26 & 6.1 \\
\hline$>60$ & 3 & 0.7 \\
\hline Total & $\mathbf{4 2 7}$ & $\mathbf{1 0 0 . 0}$ \\
\hline Working condition & & \\
\hline Not working / still in school & 96 & 22.5 \\
\hline Recently dismissed due to office / business closed & 11 & 2.6 \\
\hline Work from home & 171 & 40.0 \\
\hline Work at office & 108 & 25.3 \\
\hline Temporary off from work & 41 & 9.6 \\
\hline Total & $\mathbf{4 2 7}$ & $\mathbf{1 0 0 . 0}$ \\
\hline
\end{tabular}




\subsection{Diet During PSBB}

Table 2 shows the respondent's dietary patterns during the PSBB. As many as $40.7 \%$ of respondents always consume fresh food every day. There are many studies reported that intake of antioxidants and nutrients can help the immune system function. To maintain immune function it is recommended to eat healthy foods with balanced nutrition including colorful fruits and vegetables [14].

Nearly half respondents $(48.7 \%)$ seldom consume processed foods the past few days. The pandemic that occurred as a result of COVID-19 now clearly raises public concern. The impact is seen in changes in health behavior in the community. One factor that underwent changes during the COVID-19 pandemic was consumption of processed foods [15].
Most respondents (39.3\%) often consume vegetables and fruit every day. Government of Indonesia through the Ministry of Health suggested to encourage the community to prevent the spread of COVID-19 by increasing people's behavior and knowledge and implementing healthy and clean lifestyle every day, including by consuming fruits and vegetables [16].

Nearly half the respondents $(48.2 \%)$ always eat side dishes that contain animal protein (chicken / lamb / beef / buffalo meat). Total animal foods are whole animal food sources of protein, including side dishes such as meat, fish, eggs and non-side dishes (milk) [17]. Animal food as a source of protein for nutrient intake in order to maintain health, maintain body stamina, and increase brain intelligence [18].

Table 2 Diet During PSBB

\begin{tabular}{|l|c|c|c|c|c|c|c|c|c|c|}
\hline \multirow{2}{*}{ Variable } & \multicolumn{2}{c}{ Never } & \multicolumn{2}{c|}{ Seldom } & \multicolumn{2}{c|}{ Often } & \multicolumn{3}{c|}{ Always } & \multicolumn{2}{c|}{ Total } \\
\cline { 2 - 11 } & $\mathrm{f}$ & $\%$ & $\mathrm{f}$ & $\%$ & $\mathrm{f}$ & $\%$ & $\mathrm{f}$ & $\%$ & $\mathrm{f}$ & $\%$ \\
\hline Eat fresh food every day & 4 & 0.9 & 79 & 18.5 & 170 & 39.8 & 174 & 40.7 & 427 & 100.0 \\
\hline Eat processed food the last few days & 76 & 17.8 & 208 & 48.7 & 90 & 21.1 & 53 & 12.4 & 427 & 100.0 \\
\hline Eat vegetables and fruit every day & 6 & 1.4 & 108 & 25.3 & 168 & 39.3 & 145 & 34.0 & 427 & 100.0 \\
\hline $\begin{array}{l}\text { Eat food that contain animal protein } \\
\text { (chicken / lamb/ beef / buffalo meat) }\end{array}$ & 8 & 1.9 & 75 & 17.6 & 138 & 32.3 & 206 & 48.2 & 427 & 100.0 \\
\hline $\begin{array}{l}\text { Eat food that contain vegetable } \\
\text { protein (tofu / tempeh) every day }\end{array}$ & 8 & 1.9 & 99 & 23.2 & 189 & 44.3 & 131 & 30.7 & 427 & 100.0 \\
\hline Eat snacks every day & 72 & 16.9 & 24 & 58.1 & 81 & 19.0 & 26 & 6.1 & 427 & 100.0 \\
\hline $\begin{array}{l}\text { Eat fatty foods (contain coconut milk } \\
\text { / fried foods) in a day }\end{array}$ & 18 & 4.2 & 190 & 44.5 & 165 & 38.6 & 54 & 12.6 & 427 & 100.0 \\
\hline Eat more servings during PSBB & 115 & 26.9 & 197 & 46.1 & 91 & 21.3 & 24 & 5.6 & 427 & 100.0 \\
\hline $\begin{array}{l}\text { Accustomed to consuming vitamins } \\
\text { or additional nutrients }\end{array}$ & 82 & 19.2 & 155 & 36.3 & 110 & 25.8 & 80 & 18.7 & 427 & 100.0 \\
\hline $\begin{array}{l}\text { Used to avoid ordering fast food } \\
\text { outside }\end{array}$ & 91 & 21.3 & 116 & 27.2 & 108 & 25.3 & 112 & 26.2 & 427 & 100.0 \\
\hline Drink at least 8 glasses per day & 26 & 6.1 & 111 & 26.0 & 146 & 34.2 & 144 & 33.7 & 427 & 100.0 \\
\hline
\end{tabular}

Total of $44.3 \%$ respondents often consume food that contain vegetable protein (tofu / tempeh) every day. Vegetable protein is a vegetable food source of protein such as tofu, tempeh, soybeans, legumes and processed products [17]. Protein has many functions for our bodies both for adults and for children. The function of protein as a building block, functions in the body's defense mechanism against various microbes and other toxic substances that come from outside, regulates metabolic processes in the form of enzymes and hormones, and protein is one of the main sources of energy [19].
More than half that is $58.1 \%$ respondents seldom consume snacks every day. Snack food according to the Indonesian Nutritionists Association (2009) is food and drinks produced by informal sector entrepreneurs with small capital sold and ready to be consumed in crowded places, along roads, settlements, by traveling, settling, or a combination of the two methods. Snack food can be in the form of main or distractions. Heavy food meal or main food is food that is commonly consumed daily consisting of staple foods, side dishes, and vegetables. Snack food is a food that is often eaten outside of the time of the main food which is often also called a snack which can occur at the 
time between breakfast and lunch such as various snacks and a variety of market snacks [20]. Too often eating snacks and becomes a habit will have negative consequences, one of which is unhygienic food will cause various diseases [21].

As many as $44.5 \%$ of respondents sometimes consume fatty foods (contain coconut milk / fried foods) in a day. In the prevention of COVID-19 disease for regions during PSBB and local transmissions, nutritional services are provided in a limited manner. The information that must be submitted online is the importance of balanced nutrition, physical activity, limiting consumption of foods with high fat salt sugar, and maintaining cleanliness [8].

As many as $46.1 \%$ of respondents seldom eat larger portion during the PSBB. To be able to live a healthy and productive life, humans need about 45 types of nutrients that must be obtained from the food consumed, and no single food is able to meet all the nutritional needs of humans. To meet these nutritional needs, everyone needs to consume a variety of foods that are nutritionally balanced, and safe [22].
As many as $36.3 \%$ of respondents were sometimes accustomed to taking vitamins or additional nutrients. In the prevention and management of COVID-19, proper nutrition is needed. There are many studies that report that intake of antioxidants and nutrients can help the function of the immune system so that it can prevent disease [14].

As many as $27.2 \%$ of respondents are seldom accustomed to avoid ordering fast food outside. Efforts to prevent the spread of COVID-19 in ready-to-sell food facilities such as restaurants, cafes, canteens, restaurants, food trucks and street vendors are carried out by applying good methods of preparing processed foods or good ways of selling snacks or restaurant management the good one [23].

Most respondents, that is $34.2 \%$ often drink at least 8 glasses per day. The World Health Organization (WHO) has also given nutritional advice during the COVID-19 pandemic, which is by consuming fresh and not preserved food and drinking enough water every day (at least 8 glasses per day) [24].

Table 3 Physical Activity During PSBB

\begin{tabular}{|l|c|c|}
\hline \multicolumn{1}{|c|}{ Variable } & f & \% \\
\hline Doing physical activity or sports in the area around the house \\
\hline Yes & 317 & 74.2 \\
\hline No & 110 & 25.8 \\
\hline Total & $\mathbf{4 2 7}$ & $\mathbf{1 0 0 . 0}$ \\
\hline Frequency of physical activity & & \\
\hline$\geq 5$ times per week & 106 & 33.4 \\
\hline$<5$ times per week & 211 & 66.6 \\
\hline Total & $\mathbf{3 1 7}$ & $\mathbf{1 0 0 . 0}$ \\
\hline Duration of physical activity & & \\
\hline$\geq 30$ menit & 151 & 47.6 \\
\hline$<30$ menit & 166 & 52.4 \\
\hline Total & $\mathbf{3 1 7}$ & $\mathbf{1 0 0 . 0}$ \\
\hline
\end{tabular}

Table 3 shows physical activity during PSBB, where the results of the study found that the majority of respondents (74.2\%) engaged in physical activities or sports in the area around the house. The physical activities that are often carried out by respondents during the PSBB are washing / cooking / sweeping / mopping, walking, aerobics, playing video games, gardening etc. As much as $66.6 \%$ of respondents did physical activity less than 5 times per week. For the duration of physical activity, $52.4 \%$ of respondents did physical activity for less than 30 minutes in one activity.
Physical activity is anything that moves body and burns calories [25]. One type of physical activity is present in daily life. Daily activities in managing the house can help to burn the calories from the food we eat. For example, washing clothes, mopping, walking, cleaning windows, gardening, ironing, playing with children, and others. Calories burned can be 50-200 kcal per activity. Another type is physical exercise, which is an activity that is carried out in a structured and planned manner, for example, walking, jogging, pushups, stretching, aerobic exercise, cycling, and so on. Sport is defined as physical activity that is structured and planned by following the applicable rules 
with the aim not only to make the body fitter but also to gain achievement. Which includes sports such as football,

badminton, basketball, swimmıng, and so on [26].

It is recommended that everyone do physical activity at least 150 minutes / week. If able, a person can do it at least 30 minutes / day for 5 times a week. It doesn't matter if it's not done in one segment. It can be done 3 times a day for 10 minutes or 2 times a day for 15 minutes. For those who have problems with cholesterol and blood pressure, it is

recommended to do at least 40 minutes of moderate intensity exercise 3/4 times a week [27].

\section{LIMITATION}

Data collection in this study uses an online questionnaire so that there is the possibility of information bias. This result might also overestimate the actual condition because it is not validated by other methods.

\section{CONCLUSION}

More than half of the respondents were male. Most respondents were in the age group of 21-30 years, and most respondents work from home. More than half of respondents sometimes eat snacks every day. Nearly half of the respondents consumed fresh food every day, sometimes consumed processed food the last few days, ate side dishes containing animal protein, and sometimes ate more portions during PSBB

The physical activities that are often carried out by respondents during the PSBB are washing / cooking / sweeping / mopping, walking, aerobics, playing video games, gardening. Most of respondents did physical activity less than 5 times per week. For the duration of physical activity, most of respondents did physical activity for less than 30 minutes in one activity. It is recommended that people maintain a balanced diet and regularly carry out physical activities, especially during this pandemic.

\section{ACKNOWLEDGMENT}

This work was supported and funded by Faculty of Public Health, Universitas Andalas through DIPA FKM UNAND 2020 .

\section{REFERENCES}

[1] Kemenkes RI, Pedoman Pencegahan dan Pengendalian Coronavirus Disease (COVID-19) Revisi ke-4. Jakarta: Kementerian Kesehatan
Republik Indonesia, 2020.

[2] Kemenkes RI, “COVID-19,” 2020. https://infeksiemerging.kemkes.go.id/.

[3] Pemerintah Provinsi Sumatera Barat, "Data Pantauan COVID-19 Provinsi Sumatera Barat," 2020. https://corona.sumbarprov.go.id/.

[4] Center for Disease Control and Prevention, "Coronavirus Disease 2019: How It Spreads," 2020. https://www.cdc.gov/coronavirus/2019-

ncov/prevent-getting-sick/how-covidspreads.html?CDC AA refVal=https $\% 3 \mathrm{~A} \% 2 \mathrm{~F}$ \%2Fwww.cdc.gov\%2Fcoronavirus\%2F2019ncov\%2Fprepare\%2Ftransmission.html.

[5] Pemerintah Republik Indonesia, "Peraturan Pemerintah Nomor 21 Tahun 2020 tentang Pembatasan Sosial Berskala Besar Dalam Rangka Percepatan Penanganan Coronavirus Disease 2019/COVID-19.” Pemerintah Republik Indonesia, Jakarta, 2020.

[6] Kementerian Kesehatan RI, "Peraturan Menteri Kesehatan Republik Indonesia Nomor 9 Tahun 2020 tentang Pedoman Pembatasan Sosial Berskala Besar dalam Rangka Percepatan Penanganan Corona Virus Disease 2019 (COVID-19)." Kementerian Kesehatan RI, Jakarta, 2020.

[7] Pemerintah Provinsi Sumatera Barat, "Panduan Umum PSBB Sumbar." Pemerintah Provinsi Sumatera Barat, Padang, 2020.

[8] Kemenkes RI, Pedoman Pelayanan Gizi pada Masa Tanggap Darurat Covid-19. Jakarta: Kementerian Kesehatan Republik Indonesia, 2020.

[9] Pemerintah Provinsi Sumatera Barat, "Pertumbuhan Ekonomi Sumatera Barat Triwulan II 2020,” 2020. https://www.sumbarprov.go.id/home/news/1922 4-pertumbuhan-ekonomi-sumatera-barattriwulan-ii-2020.html.

[10] World Health Organization, “\#HealtyAtHome: Healthy Diet," 2020. https://www. who.int/campaigns/connecting-theworld-to-combatcoronavirus/healthyathome/healthyathome--healthy-diet.

[11] WHO EMRO, "Nutrition advice for adults during the COVID-19 outbreak," 2020. http://www.emro.who.int/nutrition/nutritioninfocus/nutrition-advice-for-adults-during-thecovid-19-outbreak.html.

[12] WHO, "\#HealthyAtHome - Physical Activity," 2020. https://www.who.int/news- 
room/campaigns/connecting-the-world-to-

combat-

coronavirus/healthyathome/healthyathome--physical-activity.

[13] World Health Organization, "Physical Activity," 2018. https://www.who.int/news-room/factsheets/detail/physical-activity\#: :text=What is physical activity\%3F, and engaging in recreational pursuits.

[14] Rizky Suganda Prawiradilaga, KOPIDPEDIA: Bunga Rampai Artikel Penyakit Virus Korona ( COVID-19 ). Bandung: Pusat Penerbitan Universitas (P2U) Unisba, 2020.

[15] L. J. Utama, "Gaya Hidup Masyarakat Nusa Tenggara Timur dalam Menghadapi Pandemi Corona Virus Disease 19 (Covid-19)," Annada J. Kesehat. Masy., vol. 7, no. 1, 2020.

[16] M. B. Karo, "Perilaku Hidup Bersih dan Sehat (PHBS) Strategi Pencegahan Penyebaran Virus Covid-19," in Prosiding Seminar Nasional Hardiknas, 2020, vol. 1, no. 1, pp. 40-47, doi: 978-602-202-076-9.

[17] A. Hardiansyah, Hardinsyah, and D. Sukandar, "Kesesuaian Konsumsi Pangan Anak Indonesia dengan Pedoman Gizi Seimbang," Nutr. Sains, vol. 1, no. 2, 2017.

[18] D. Wahyuni, L. Purnastuti, and M. Mustofa, "Analisis Elastisitas Tiga Bahan Pangan Sumber Protein Hewani Di Indonesia," J. Econ., vol. 12, no. 1, p. 43, 2016, doi:

10.21831/economia.v12i1.9544.

[19] F. M. Diana, "Fungsi dan Metabolisme Protein dalam Tubuh Manusia," J. Kesehat. Masy., vol. 4, no. 1, p. 49, 2009, doi: 10.1098/rspb.2000.0961.

[20] A. Nurhayati, E. Lasmanawati, and C. Yulia, "Pengaruh Mata Kuliah Berbasis Gizi Pada Pemilihan Makanan Jajanan Mahasiswa Program Studi Pendidikan Tata Boga," J. Penelit. Pendidik., vol. 13, no. 1, pp. 1-6, 2012.

[21] K. Irianto and K. Waluyo, Gizi \& pola Hidup Sehat. Bandung: CV.Yrama Widya, 2007.

[22] A. Suryana, "Penganekaragaman Konsumsi Pangan dan Gizi: Faktor Pendukung Peningkatan Kualitas Sumber Daya Masyarakat," Pangan, no. 52, pp. 1-16, 2008.

[23] Badan POM, Pedoman Produksi dan Distribusi Pangan Olahan pada Masa Status Darurat Kesehatan Corona Virus Disease 2019 (COVID19) di Indonesia. Jakarta: Badan Pengawas Obat dan Makanan RI, 2020.

[24] N. S. Hadi, "Peran Coklat dalam Penanganan
Stress Saat Work From Home dan Kesehatan Mata Saat Terpapar Radiasi Online," in Prosiding Seminar Nasional Hardiknas, 2020, pp. 65-70.

[25] American Heart Association, “American Heart Association Recommendations for Physical Activity in Adults and Kids," 2018. https://www.heart.org/en/healthyliving/fitness/fitness-basics/aha-recs-forphysical-activity-in-adults.

[26] Kementerian Kesehatan RI, "Mengenal Jenis Aktivitas Fisik," 2018. http://promkes.kemkes.go.id/content/?p=8807.

[27] Kementerian Kesehatan RI, “Aktivitas Fisik 150 Menit per Minggu Agar Jantung Sehat,” 2018. http://www.p2ptm.kemkes.go.id/infographicp2ptm/hipertensi-penyakit-jantung-danpembuluh-darah/aktivitas-fisik-150-menit-perminggu-agar-jantung-sehat. 